\title{
膵臓移植手術手技の進歩
}

\section{杉谷 篤*}

要 旨：膵臓移植あるいは膵腎同時移植は本邦でも増加している. 特に, 2010 年 7 月の臓 器移植法改正後, 脳死ドナーからの膵臓提供が増えて多くの認定施設で施行されるように なってきた. 本稿では, 最近の膵臓移植の手術手技について, 脳死ドナーと心停止ドナー からの膵臓摘出術, 移植施設における Bench surgery, レシピエントに対する膵単独移植あ るいは膵腎同時移植の手術手技を述べる.

膵臓摘出もふくめたドナーの多臓器摘出手術は, 血管内潅流 (Core cooling) とともに表 面冷却 (Surface cooling) を併用する Super rapid technique が臓器の Viability を保ち, 脳 死でも心停止でも対応でき, 簡便・安全な方法である. 小腸や肝臓に血管を優先的に供与 するので, 膵頭部と膵体尾部の血流を保持し 1 本化するための Bench surgery が必要とな る.レシピエント手術は右腸骨窩の腹腔内で腸骨動静脈に端側吻合し, 膵液ドレナージを 腸管か膀胱に行うことが多い. 膵腎同時移植の場合は, 対側の腹膜外腔に腎移植を行う. 本稿では, 日本の膵臓移植が医学的・社会的状況に応じて進化・変遷し, 現時点でもっと も妥当と思われる手術手技を概説した.

\section{索引用語 : 膵臓移植＼cjkstart膵腎同時移植 脳死ドナー 1 型糖尿病 慢性腎不全}

膵臓移植あるいは脺腎同時移植は本邦でも増加 している. 特に, 2010 年 7 月の臓器移植法改正後, 脳死ドナーからの膵臓提供が増えて多くの認定施 設で施行されるようになってきた，本稿では，最 近の膵臓移植の手術手技について, 脳死ドナーあ るいは心停止ドナーからの膵臓摘出術, 移植施設 における Bench surgery，レシピエントに対する 膵単独移植あるいは膵腎同時移植の手術手技につ いて詳述した。

\section{脳死ドナーからの膵臓摘出手技}

\section{1. 小腸 - 肝臓・膵臓・腎臓の摘出手技}

脺蔵摘出のみならずドナー手術全般に対する基 本的な考え方は, (1)臟器の Viability が最も良くな るような摘出・保存方法であること, (2)脳死でも 心停止でも対応できる方法であること, (3)膵蔵あ るいは腎臓のみでなく, 多臓器摘出も可能な方法 であること, (3)術前あるいは術中に出血, 心停止

\footnotetext{
*藤田保健衛生大学臟器移植再生医学講座
}

などクラッシュした場合でも対応できる方法であ ること, (4)軽装備, 少人数で, いつでも, どこで も出動できる方法であること, (5)医学的, 社会的 状況に応じて進化する方法であること, に要約で きる。

欧米における腹腔内臓器の摘出法の変遷から, 最近では膵臓摘出においては en-bloc 肝膵摘出法 が標準的である。本邦の場合には各臓器の摘出 チームが参集するため, 血管内潅流, 表面冷却が 終わると, 小腸, 肝臓, 膵蔵, 腎臓の順で各チー ムが摘出することが多くなっている.いずれの場 合でも, 摘出時間短縮のために門脈カニュレー ションをしないこと, 臓器の manipulation をでき るだけ少なくすること, 不意の心停止にも対応で きる工夫をしていることがあげられる.

膵蔵は肝臓と小腸に挟まれており, 膵臓摘出は 小腸と肝臓の摘出の有無と手技によって異なるこ とになる。

(1)腹部臓器のみのときは胸骨下部から恥骨まで, 心あるいは肺も摘出するときは胸骨上縁から恥 


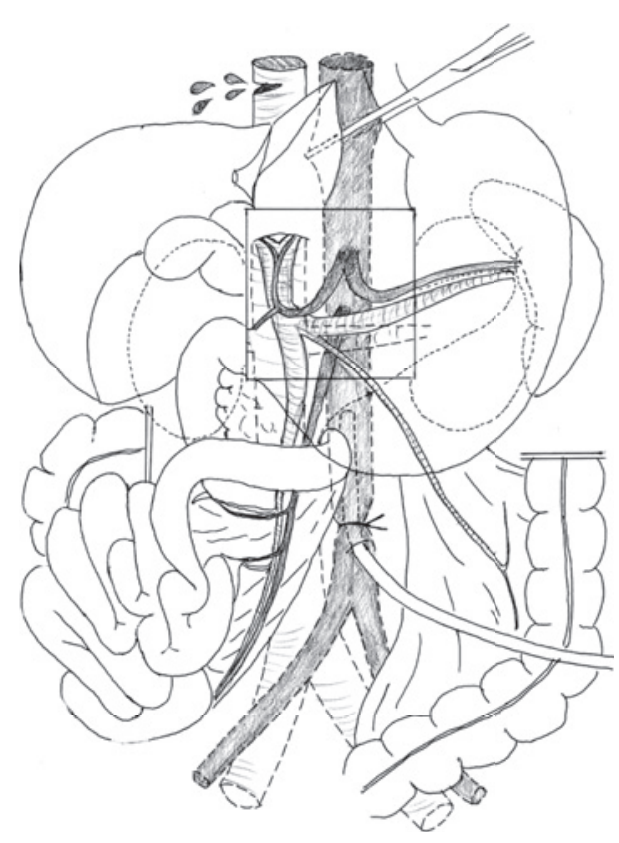

Fig. 1 大動脈カニュレーション

骨までの皮切を加え, 開胸, 開腹を同時に行う. (2)開腹後, 腹水の有無, 腸管拡張, 腸管壁肥厚の 有無を確かめて, 小腸の摘出が可能かどうかの 判断を行う. 小腸が摘出可能であれば, 小腸お よび上行結腸の一部の周囲からの剥離操作が行 われる．血管は，上腸間膜動静脈 (SMA, SMV) から右結腸動静脈 (RCA, RCV) が分岐するよ りも末梢側の部位で腸間膜を切開し, SMA, SMV の切離予定部位を露出しておくが, 腸管 浮腫を予防するために manipulation は最小限 にしてテーピングはしない.

(3)肝臓の視触診を行い, 必要があれば迅速肝生検 を行って脂肪化の程度を診断し, 肝摘出の有無 を決める。

(4)小網と大網を一部切開して, 脺前面を視触診し, 脺実質の大きさ, 色調, 硬度, 脂肪浸潤の有無 を判断し適応を決定する. 以前は胃管を十二指 腸まで挿入しイソジン液 $200 \mathrm{~m} l$ を注入してい たが，最近は行っていない.

(5)小腸を濡れた柄付きガーゼかタオルに包んで愛 護的に右側に圧排し, 腸骨動脈分岐部直上の大 動脈前面を露出する. 大動脈に約 $2 \mathrm{~cm}$ の間隔で
2 本テーピングし, カニュレーションの準備を する.腰動脈があれば, 必要に応じてへモクリッ プをかけておく. 右胸腔に脱血できない場合は, 同様な高さで下大静脈もテーピングしてカニュ レーションの準備をしておく.

(6)肝左葉を授動し, 食道・胃接合部を左によけて, 左右の横隔膜脚を切開し，この部で大動脈に テーピングしておく．ここまでの操作で大動脈 にカニュレーションとクランプがいつでも可能 となり，ドナーの急激な血圧低下や心停止に対 処できる.

(7)小腸の摘出がない場合には, 肝・膵 - 腎周囲組 織の剥離を行うが, 小腸の摘出を先行するとき は, この時点で大動脈カニュレーションに移る. ヘパリン約 2〜 3 万単位を静脈内に投与し, 約 3 分待って大動脈カニュレーションを始める (Fig. 1).

(8)下部大動脈にかけておいた 2 本のテープのう ち, 未梢側のテープを用いて腸骨動脈分岐部直 上の大動脈を結紮する. その $2 \mathrm{~cm}$ 中枢側の大動 脈を左手の第 1 指，第 2 指の指先でしっかりと つまみ, 約 $1 \mathrm{~cm}$ の横切開を加える. 大動脈用力 ニューラまたは $6 \mathrm{Fr}$ の気管内チューブを代用 し, 大動脈内に留置して血管とカニューラを しっかりと結棌する。 その際, カニューラをあ まり梁く挿入すると腎動脈の灌流が悪くなるの で注意する，UW 液の潅流を $1 \mathrm{~m}$ の高さから開 始して血管内潅流 (Core cooling) を行う，大動 脈の横隔膜部にかけておいたテープを引きなが ら，できるだけ頭側に近い部位で腹腔動脈を損 傷しないようにクランプをかける.

(9)脱血は右横隔膜の前腹壁付着部近傍を切開して 右開胸し, 肝上部下大静脈または右心房に切開 を入れ右胸腔内へ行う。これは横隔膜の隔壁効 果を利用して，下半身の温かい血液と肝膵腎を 潅流してきた冷たいUW 液を胸腔内へ誘導し, 腹腔内が温まらないようにするためである。し かし，本邦の脳死ドナー手術では肺を摘出する 場合が多く，肺摘出チームの要請で右肺が温ま らないように下大静脈に脱血カニューラを挿入 して自然落下させる場合が多い.また,このと きまで開胸しないようにして全身臓器の酸素化 

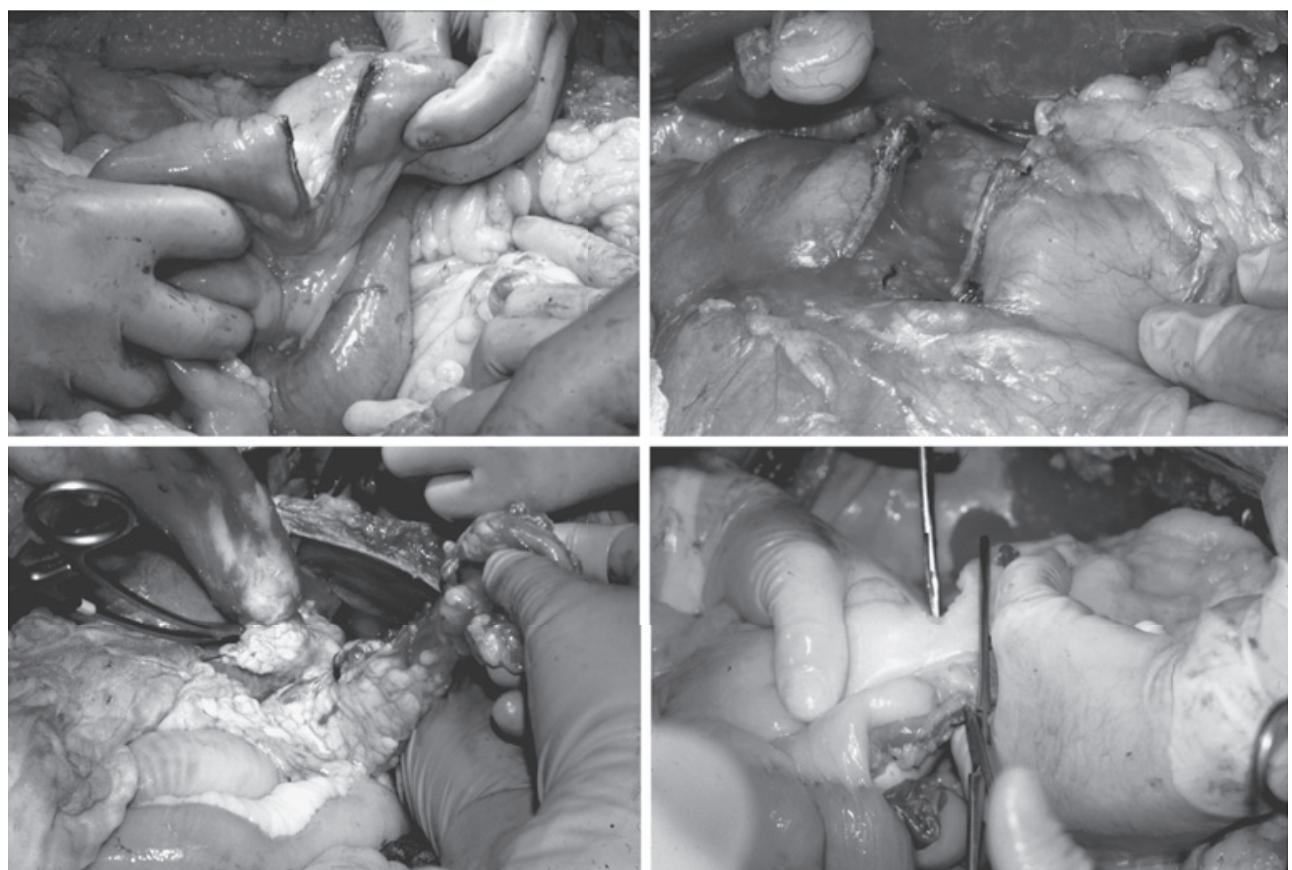

\begin{tabular}{l|l}
$\mathrm{a}$ & $\mathrm{b}$ \\
\hline $\mathrm{c}$ & $\mathrm{d}$
\end{tabular}

Fig. 2 脳死ドナー手術

を保つようにする。

(10スラッシュアイスを腹腔内, 特に肝周囲, 膵前

面，腎後面に入れ，表面冷却（Surface cooling） を行う。各臓器の灌流状態が良好であるかを確 認する．両側の腎臓は背側の腸腰筋から剥離し て腎背側にスラッシュアイスをいれておく。

UW 液は粘稠度が高いため, 滴下速度がしだい に遅くなるが, 肝・膵・腎の灌流には全量約 $2 l$ で十分である.

11最初に小腸を摘出する．空腸は Treiz 䩲帯より 約 $50 \mathrm{~cm}$ の部位で GIA を用いて離断 (Fig. 2a), 右側結腸は授動して肝彎曲部で GIA を用いて 離断, 切離部位をつなげるように腸間膜を膵下 縁から距離をおいて切開して小腸を摘出する。

(12)次いで, 肝臓の摘出を行う。本邦の肝臓摘出の 場合, 肝動脈を胃十二指腸動脈 (GDA), 総肝動 脈 (CHA) で離断することが多く, 門脈は脾静 脈が合流したあとの膵上縁で離断することが多 い.

(13)膵臓の摘出は, 胃の遊離, 脱転から始まる. 小
彎側は剥離されているので, 大網, 短胃動静脈 を胃壁寄りで切離し胃を完全に遊離する。幽門 部を挙上しながら，胃前庭部を GIA で切離し， 胃を胸腔内あるいは胸壁上に脱転しておく (Fig. 2b).

(14)右側結腸の切離断端から S 状結腸までの腸間 膜を腸管付着部で切離し, また後面の fusion fascia も切離して全結腸を遊離する. 全結腸を 腹腔外の下半身側に引き出しておく.

(15)脾臓を後腹膜から遊離し, 膵臓には出来るだけ 触らないように膵後面を脾動静脈とともに切離 して大動脈左縁に到達する (Fig. 2c). 腹腔動脈, 上腸間膜動脈, 左腎動脈が大動脈から分岐する ところは強勒な神経節と線維組織に被覆されて おり, 同部の切開, 分離がドナー手術のなかで 最も熟練と慎重さが要求される箇所である. 硬 い索状物として触れる上腸間膜動脈の左縁を露 出する. 助手に動脈周囲結合組織を 2 本のセッ シで展開してもらいながら, けっして右側に切 り达まないようにする. 右肝動脈が分岐してい 
る場合，不意に傷つけないためである，上腸間 膜動脈左縁を大動脈壁が見えるところまで切離 すると, 確認しておいた神経節に到達する。こ の神経節のみを切開するが, このあたりの組織 は，大きさ，硬さにかなり個人差があり，勢い あまって腎動脈を切らないように注意する。上 腸間膜動脈の分岐部下縁を確認したら，同部の 大動脈壁に小切開を加えて, 内腔を見ながら両 側腎動脈に十分なパッチを残すようにして大動 脈を背側まで切離する。大動脈内に指を入れて 大動脈を脊椎から切離し, 胸部大動脈クランプ 直下で大動脈を完全に切離すると膵臓が摘出さ れる。

16両側の尿管を腸骨動脈をまたぐ部位でペアン鉗 子をかけて挙上し, カニュレーションをした大 動脈と下大静脈をカニューラごと挙上して椎体 の前面を切離してくると, 両側の腎臟も挙上し て一塊として摘出できる. Bench surgery で左 右に分離する.

171分な長さの内外腸骨動脈を採取する.このと きに強く牽引すると分岐部の内膜損傷を起こす ので注意する. 特に全膵移植では, Bench surgery で脾動脈と上腸間膜動脈を Y グラフトで 一本化するので大切である. 原則的には, 左右 の動脈グラフトを二分して肝と脺にそれぞれ供 与するが, 必要なら小腸にも配分する. 同様に して, 左右の腸骨静脈を採取し二分する。膵藏 の場合, 門脈の延長グラフトとして用いる.

\section{2. 肝臓・膵臓・腎臓の摘出手技}

小腸摘出がない場合は, (1)肝・膵・腎を順次摘 出していく場合, (2)肝・膵を en-bloc で摘出し Bench surgery で両者を分ける場合, (3)肝を摘出 し, 膵・腎を en-bloc で摘出して Bench surgery で分離する場合などがある。いずれの場合にも大 動脈クランプの前に, 小腸の viabilityを気にしな くて良いので, 肝周囲の剥離, 膵・腎の授動を先 行させることができる.

(1)前項で述べたように, 肝・膵の視触診, 必要が あれば肝生検を提出する。結果を待つ間に力 ニュレーションの準備をする. 小腸を右側に圧 排し, 大動脈と下大静脈にテーピングしておく. 肝左葉を授動して, 横隔膜の高さで大動脈に
テーピングしておく.

(2) Kocher 授動術を行い, 肝下部下大静脈, 左右腎 静脈, 上腸間膜動脈から分岐する右肝動脈が肝 十二指腸靫帯の背側で触れないかを確認してお $<$.

(3)肝十二指腸間膜の膵上縁で総胆管を切離, 肝動 脈周囲組織を剥離して, 固有肝動脈( $\mathrm{PHA}$ ), 胃

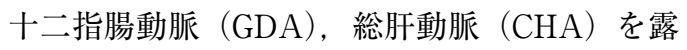
出しておく.

(4)小網と大網を切開して, 幽門輪直上と Treiz 勒 帯から約 $15 \mathrm{~cm}$ の空腸の 2 カ所にテーピングし ておき，後の腸管離断の目安とする．このとき 腸間膜を大きく結紮切離する必要はない.

(5)両側腎臓を背側の腸腰筋から起こしておく.

(6)胸腔チームと時間を合わせて全身へパリン化が すめば, 前項と同様に大動脈, 下大静脈にカニュ レーションし，潅流を開始する．直ちにスラッ シュアイスを入れて表面冷却を行い, 心蔵の摘

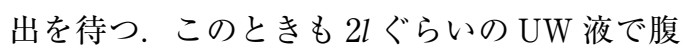
部臟器は十分に潅流されている.

(7)肝をはじめに摘出するときは, GDA, CHA で動 脈を離断, 膵上縁で門脈を離断して肝十二指腸 䩲帯を完全に離断する. 胃小弯側の血管を肝臓 側につけて切離し，下大静脈を腎静脈合流部よ り頭側で離断する. 左手で肝臓を抱きかかえて, 肝右葉背側と肝上部下大静脈周囲の横隔膜, 横 隔膜脚の筋肉の一部, 右副腎を離断して肝臓が 摘出できる.

(8)膵の摘出は, 前項(13), (14), 15)に述べた方法と同 様に行うが, 腸間膜は小腸寄りで切離する (Fig. $2 \mathrm{~d})$.

(9)腎臓の摘出も前項と全く同様である.

\section{3. 肝臓と膵臓の分離方法}

肝膵を en-bloc で摘出したときは, スラッシュ アイスを入れた Bench surgery で分離する.

(1)あらためて肝膵の視触診を行い, 動脈の切離に 移る. 腹腔動脈根部から左胃動脈の分岐部を露 出し, 左肝動脈が分岐していなければ, 左胃動 脈を結䅨, 切離する. 左肝動脈が左胃動脈から 分岐しているときは，その分岐の末梢で左胃動 脈を結㮃切離する. 腹腔動脈の根部は肝臓側に 付けるように, 脾動脈を腹腔動脈から分岐した 

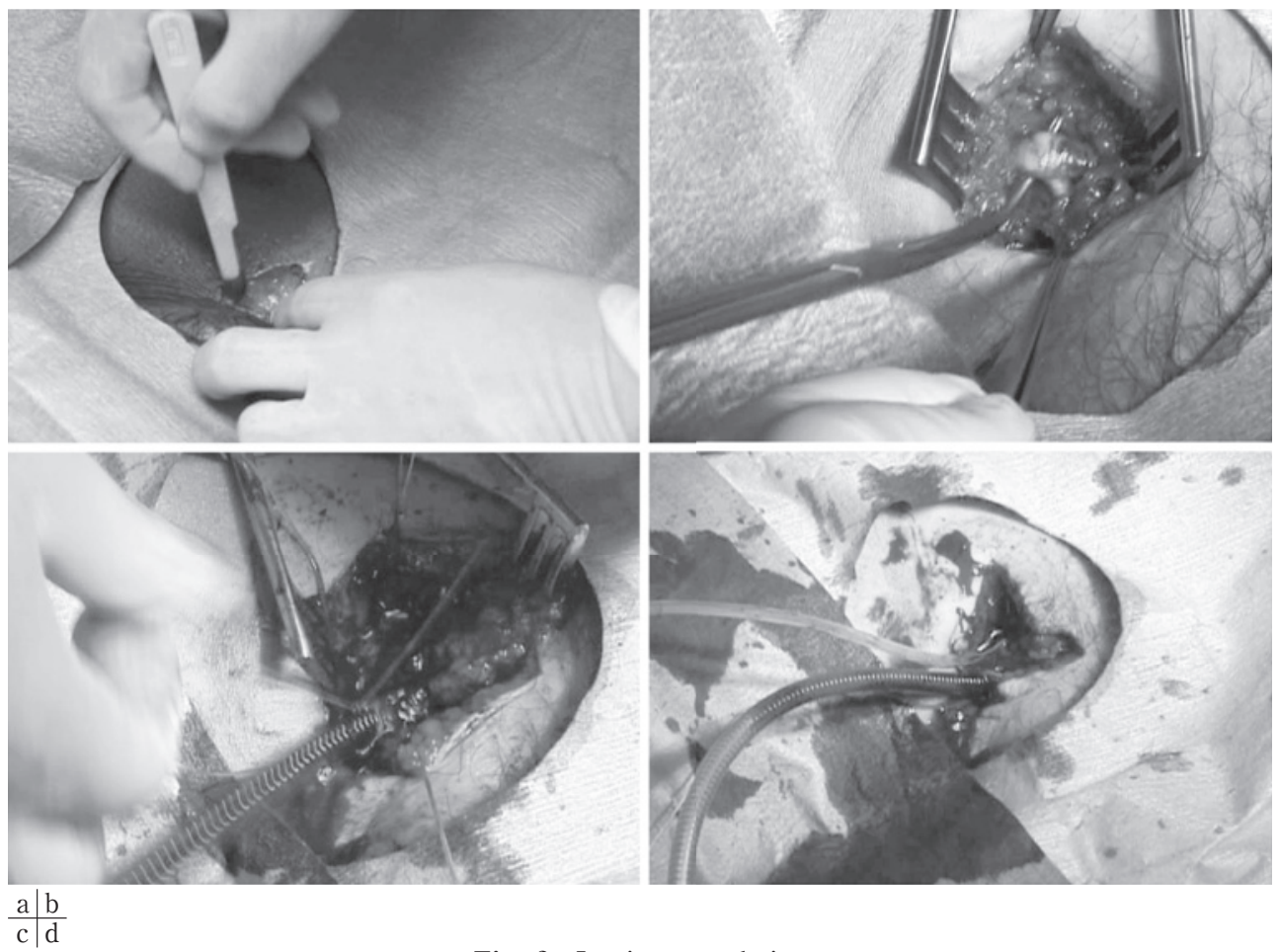

Fig. 3 In-situ cannulation

すぐ末梢側で切離する.CHA をさらに肝側へ向 かって剥離し GDA を根部で切離する.

(2)右肝動脈が上腸間膜動脈から分岐していない場 合，上腸間膜動脈と腹腔動脈はそれぞれパッチ を付けて分離する. 分岐している場合は, 右肝 動脈を少しずつ膵頭部後面から剥離していく. 多くの場合分離が可能であって, 右肝動脈の存 在だけで膵臓を犠牲にする必要はない.

(3)膵上縁のレベルで総胆管と肝動脈の後面を検索 して門脈を同定し，離断する。これで肝と膵は 分離される．膵臓の保存液は UW 液を用いる. 清潔なビニール袋に冷却 UW 液を満たし, 摘出 した膵臓と腸骨動静脈を入れて, さらに外層を 二重にビニール袋で包み, 水を満たしたクー ラーボックスに収納する。

\section{心停止ドナーからの膵臓摘出手技}

本邦における「心停止ドナーからの腎臓摘出」 は, 各都道府県単位で構成されるローカルチーム が提供病院に出動し,「一般的脳死」診断ののち,
心停止前に In-situ cannulationを行うことが多 い. 本項では法的脳死判定が行われた後に, 心停 止を待って膵臓と腎臓を摘出する方法を述べる. 脳死からの膵臓摘出の項で述べたように, 膵臓摘 出の条件, 摘出チームと摘出道具, 潅流 - 保存液 は心停止ドナーでも同様で, 摘出手技も脳死ド ナーでも心停止ドナーでも基本的に同じである. 心停止が近いと思われるときの In-situ cannulation や Respirator off は, 移植腎の生着率を向上 させることは報告されており，可能であれば好ま しいと思うが, できない場合も多いため迅速操作 に心がけて最善の努力をしなければならない.

\section{In-situ cannulation による死体内潅流と膵} 臟摘出手技

一般的脳死診断を経て心停止を迎える場合，あ らかじめ家族の承諾を得たうえで，血圧が 50 $\mathrm{mmHg}$ 以下に低下すると, ベッドサイドで大腿動 静脈から In-situ cannulation を行う. 左右どちら かの鼠径部を約 $3 \mathrm{~cm}$ 横切開し (Fig. 3a), 大腿動脈 からダブルバルーン・カテーテルを挿入する 
(Fig. 3b). あらかじめバルーンを清潔水で膨張さ せ, 注入量と漏れがないことを確認し, 体表上で 剣状突起直上に先端バルーンが来るように目測し て，おおよその挿入距離を記憶する．脱血ライン は, 大腿静脈から心臓外科手術で用いる体外循環 用の太いスパイラルカテーテルを下大静脈まで十 分に挿入固定し, 通常の蓄尿バッグに連結しクラ ンプをかけておく(Fig. 3c). 挿入したらカテーテ ルを固定してヘパリン 20,000 単位を注入し, 潅流 開始までは点滴セットに生食水を連結しておく (Fig. 3d).

その後, 摘出チームを, 手術室で手洗いをして 摘出手術に備える 1 2 名とドナー病室担当の 1 2 名に役割分担する, 死亡宣告後, ダブルバ ルーン・カテーテルより潅流を開始し手術室に搬 送する. 手術室チームは, 清潔操作で持参した手 術器械を展開し, 消毒用のイソジン液を小ベース ンに, 腎臓を分離する bench surgery 用の水冷水 を中ベースンに，開腹後ただちに腹腔内に入れる スラッシュアイスを大ベースンに入れて準備して おく. 病室担当は心停止に続いて主治医の死亡宣 告後, 必要であれば検死や看取りの時間をとって から, 大動脈内のバルーンを膨らませて冷却した $\mathrm{UW}$ 液を高さ $1 \mathrm{~m}$ から自然落下させて潅流開始,

脱血ラインを開放し，ドナーをすみやかに手術室 に搬送する。

2. In-situ cannulation ができない場合の死体 内潅流と膵臓摘出手技

一般的脳死判定がなされない場合, In-situ cannulation はできない.この場合には, 死亡宣告後, 急いで手術室に搬送してもらう。ただちに開腹下 で cannulation を行う. 開腹して大動脈を確認し, 腸骨動脈分岐部直上を素早く $2 \mathrm{~cm}$ 剥離する. 約 2 $\mathrm{cm}$ 尾側にペアン鉗子をかけて末梢側を遮断し, 大動脈に切開を加えて, 小児用の気管内チューブ $6 \mathrm{Fr}$ を挿入し結紮する.ささらにチューブそのもの も結紮固定する.小網をあけて横隔膜脚を確認し, その下に走る大動脈を腹腔動脈より頭側でペアン 鉗子をかける，脱血に関しては，剣状突起右側の 肝上部横隔膜を切開して右胸腔を開き, 肝上部下 大静脈を切開して右胸腔に脱血，吸引する。 これ は, 腹部下大静脈の切開, 脱血をしないので, 血
液が腹腔内に流出して視野を妨げるのと腹腔臓器 が温まってしまうことを回避する方法で, 時間も 短縮することができる. 冷却 UW 液にて潅流を開 始するとともにスラッシュアイスを入れて表面冷 却をする.

\section{3. 膵・腎摘出手技}

(1)ドナーを手術台に移したら，胸腹部前面をイソ ジン液ですばやく消毒し, 滅菌した大シーツを かける。 日本藏器移植ネットワークコーディ ネーターの指示に従い, ドナーに黙䘠を捧げた 後, 剣状突起から恥骨結合までの腹部正中切開 で開腹し, 癒着, 損傷がないこと, 小腸・肝臓 の表面が潅流されて白色調になっていることを 確認する.

(2)結腸の肝彎曲部と脾彎曲部の背側をセーレで切 開し, 用手的に右腎, 左腎を腎周囲組織ともど も背側の腸腰筋から剥離してスラッシュアイス を入れるポケットを作成する. 大ベースンに入 れた氷冷水を素早く腹腔内に入れ, 腹腔内臓器 の表面冷却を行う。特に腎の背側と, 小網を切 開して胃背側, 膵前面にスラッシュアイスをす みやかに入れることが重要である.

(3)膵臓・腎臓の摘出の場合, まず膵臓を摘出して おいて両腎を一塊で摘出する方法と, 膵臓・両 腎を一塊で摘出してそれぞれを分離する方法が ある. 原則として摘出手技は肝臓摘出のない脳 死ドナーからの膵・腎摘出と同じであるので, 詳細は脳死ドナーの章を参照されたい.

以下に膵臓と両側腎を別個に摘出する際の手技 の流れを示す.

(4)幽門部と空腸を GIA で離断し, 小腸間膜を小腸 寄りで切離する.

(5)肝動脈・総胆管, 門脈を肝門部よりで離断し, 膵頭部を Kocher 授動術にて大動脈右壁まで脱 転, 膵体尾部と脾臓を後腹膜より遊離し, 大動 脈左壁まで授動する。上腸間膜動脈根部から斜 めに切開し, 腹脘動脈, 上腸間膜動脈を含む大 動脈パッチとして膵蔵が摘出される.

(6)その後, 両腎の一塊摘出を行う. 両側の尿管を 腸骨動脈をまたぐあたりで切離し，尿管周囲組 織とともにモスキートペアンで把持し腎臟側へ 遊離挙上する。 

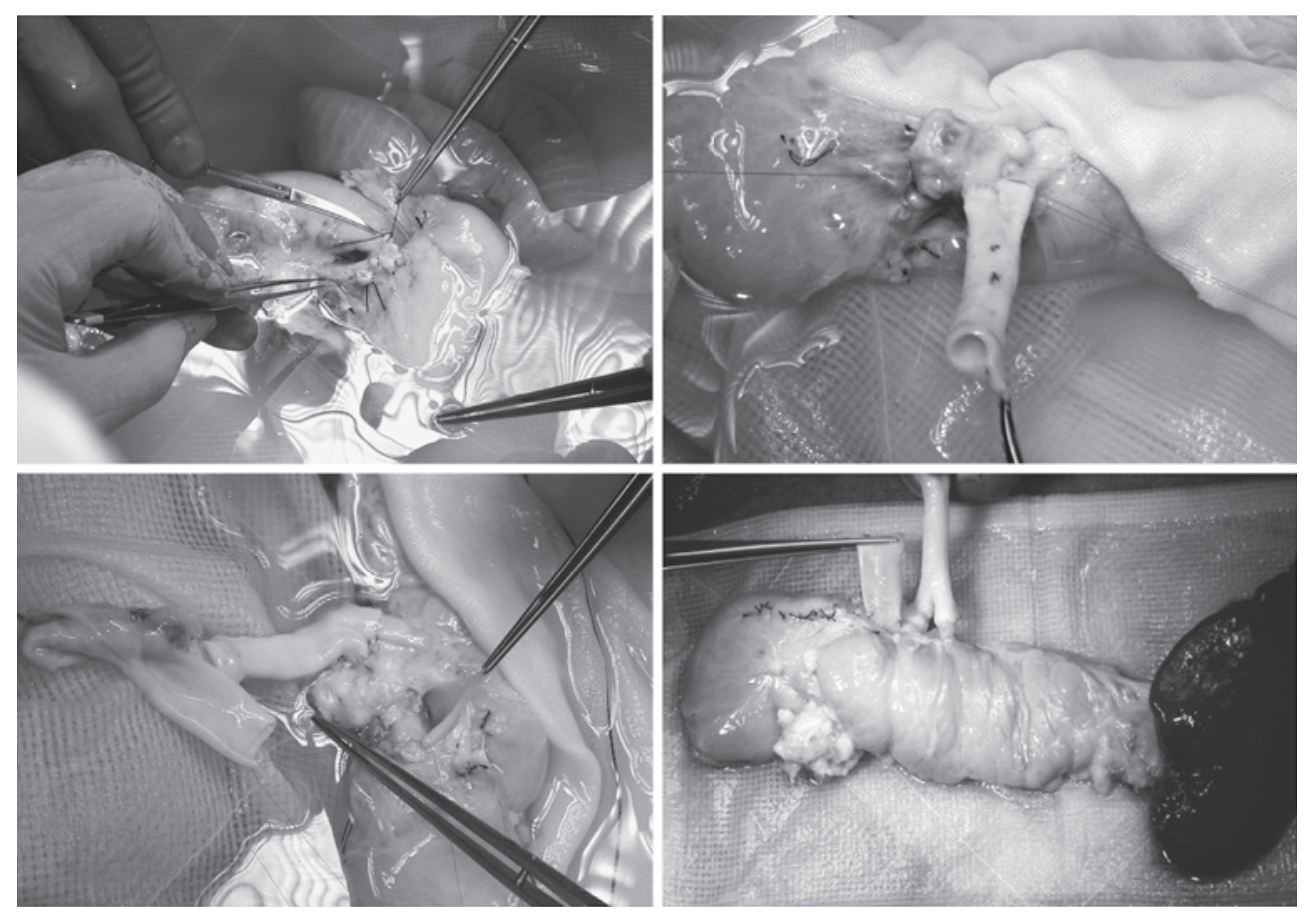

$\frac{\mathrm{a} \mid \mathrm{b}}{\mathrm{c}} \mathrm{d}$

Fig. 4 膵グラフトの Bench surgery

(7)腎臓を周囲組織から遊離する。腸管を挙上して 腎臓前面を露出する.

(8)大動脈と下大静脈を腎動静脈流入部に注意し て, 完全に離断し, 血管を夾椎から切離し一塊 として摘出する.

(9)移植前の血管形成の可能性もあるため, 左右の 腸骨動静脈を十分な長さで採取する.

\section{4. 摘出後の注意}

血管の末梢側にかけたペアン鉗子等の腹腔内の 手術機械は, 膵・腎摘出後に血管を結紮してから 確実に回収し, 閉腹前に器械の定数カウントを行 う。摘出までに時間がなかったり, 摘出前の情報 がそしい心停止ドナーの場合, 腎臓を摘出したあ と, 十分に腹部を観察し, 損傷・出血・感染の有 無, 肝硬変の有無, 特に消化管, 肝臓, 膵臓に肉 眼的に判別できる悪性腫瘍がないことを視診・触 診で確認する. 閉創は生体の手術のときと同様に, きれいな連続綘合で行い, さらにテープを貼って ドナーのご遺体を清拭する.

\section{膵グラフトの Bench surgery}

ドナー病院での Bench surgery は各臓器を分 離するだけで周囲組織がついたままであるが，レ シピエント病院に膵臓を持ち帰ってからの Bench surgery における移植医の判断, グラフト の処理は, 全膵移植を成功させる大きなポイント である。膵臓と肝臓が摘出される場合, 前述した ように, 腹脭動脈, 肝動脈, 門脈は膵臓, 肝臓に 共通の血管であるため, 膵グラフトの血行再建が 必要となる。肝臓を摘出しない場合は血行再建が 不要となる。

(1)浅めのトレイに氷を入れ, ビニールを敷き, 冷 えた Lactate Ringer 液を満たす (Fig. 4a). 膵臓 の大きさ, 膵実質の色調, 硬度, 脂肪浸潤の程 度, 損傷の有無, 動脈硬化の程度, 潅流状態を 再度チェックする。

(2)総胆管断端の結紮糸をはずして，8Frのアトム チューブを挿入しV Vater 乳頭の位置を確認す る.この部分を損傷しないようにして十二指腸 
の両側を膵頭部から少しずつ遊離し, 可能なら ば約 $7 \mathrm{~cm}$ に短縮する。口側断端は GIA で切除 したあと Lembert 縫合を結節で行う. 肛門側断 端は GIA で切除閉鎖した状態とする. 移植手術 のとき，腸管吻合を端側で行う場合はこの部を 追加切除して用いる. 側々吻合あるいは膀胱と の側々吻合を行うときは, そのときに肛門側断 端を Lembert 結節縫合で閉鎖する. 総胆管断端 はあらためて二重結紮しておく.

(3)腸間膜根部, 結腸間膜, 膵上下縁の血管, 結合 組織を結枆切離する.このとき太い血管は二重, 三重結紮をしてゆるまないようにするが, 血管 のみを剥離して結紮すると, 再潅流のとき血管 周囲組織からも思わぬ出血が起こる，また腸間 膜をあまり膵に近いところで結紮すると, 下膵 十二指腸動脈を損傷することがある.

(4)膵グラフトの脾動脈, 上腸間膜動脈および腸骨 動脈グラフトの口径, 硬化の程度をよく観察し, 内膜摘除が必要かどうか, どのような吻合を行 うかを決定する. 一般的には, 腸骨動脈を $\mathrm{Y}$ グラフトとし，外腸骨動脈を上腸間膜動脈に， 内腸骨動脈を脾動脈に吻合し, 総腸骨動脈をレ シピエント腸骨動脈との吻合に用いる (Fig. 4b). 上腸間膜動脈の口径が大きく外腸骨 動脈が小さい場合は血流量が少なくなるので, 逆 Y グラフトにして総腸骨動脈を上腸間膜動 脈に吻合し，外腸骨動脈をレシピエント腸骨動 脈との吻合に用いることもある。また, 上腸間 膜動脈が太く, 長い場合, 腸骨動脈の一部を用 いて脾動脈との間に interposition graft を置く こともある. 欧米では一般に胃十二指腸動脈の 断端を結紮しており, 膵頭部と十二指腸の血流 は上腸間膜動脈からのアーケードでまかなわれ ることになるが，まれに十二指腸の血流が良く ない症例があったので, 本邦においては再建す ることが多い. 動脈は冷却と操作によって口径 が極端に小さくなっており, 再潅流後しばらく して狭窄を起こすことがあるので, 吻合は growth factor を置いた非吸収糸 6-0 7-0の 連続縫合で行っている。このときに移植された 状態での立体関係や, 腸管吻合あるいは膀胱吻 合に伴うねじれも想定して吻合の角度, 動脈グ
ラフトの方向を決めることが大切である．また 吻合を結節縫合で行ってもよいが, bench surgeryを短時間で終了し全体の虚血時間をでき るだけ短縮すること, 臓器の manipulation をで きるだけ少なくするように心がけることはコツ のひとつである.

(5)多くの場合, 門脈は上腸間膜静脈と脾静脈の合 流部の肝側で切離されているので, 総腸骨静脈 の太い直線部分を用いて延長しておく (Fig. 4c). 吻合には非吸収糸 6-0 を用いた連続 縫合で, growth factor を置いておく. 脾静脈が 切離されていたり, 切り达まれている場合は, 内外腸骨静脈分岐部を利用して形成することも ある。

(6) 原則的に脾臓は bench surgery では摘除しな い. 膵体尾部の血流を良好にするためと膵尾部 への損傷をさけるために, 移植, 再再潅流をし たあとで摘除する．脾門部で脾動静脈が同定で きるものは剥離しておくとよい. また, 脾周囲 の血管, 特に短胃動静脈の断端は出血するので 結紮しておく.

(7)約 $1 \mathrm{~m}$ の高さから冷えた UW 液を動脈グラフ トから滴下し，漏出部位を結紮する (Fig. 4d). 膵実質の潅流状況, 静脈グラフトからの流出状 態を観察する。ゆっくりと継続的に流出してく ればよい，若干の残留血液がでてくるが, 膵実 質の血流はもともと緩徐なので, 流量や潅流圧 を上げすぎないほうがよい.

以上の操作が終了したら, レシピエントの術野 にあげるまで冷却した保存液 (UW 液) に浸して おく.さらに, 膵グラフトを術野にあげたのちも, この bench surgery のセットと保存液はレシピエ ント手術が終了するまで傍らに清潔のままおいて おく．これは膵グラフトを再潅流しても血流が良 好でなかったり，レシピエント動脈に血栓ができ た場合などに再摘出, 再潅流・冷却をする必要が 生ずるからである.

\section{膵臓移植の手術手技}

膵単独移植あるいは膵腎同時移植のレシピエン 卜手術も時代により，また施設により異なってい る. 腹腔内か腹膜外腔か, 十二指腸を頭側に向け 

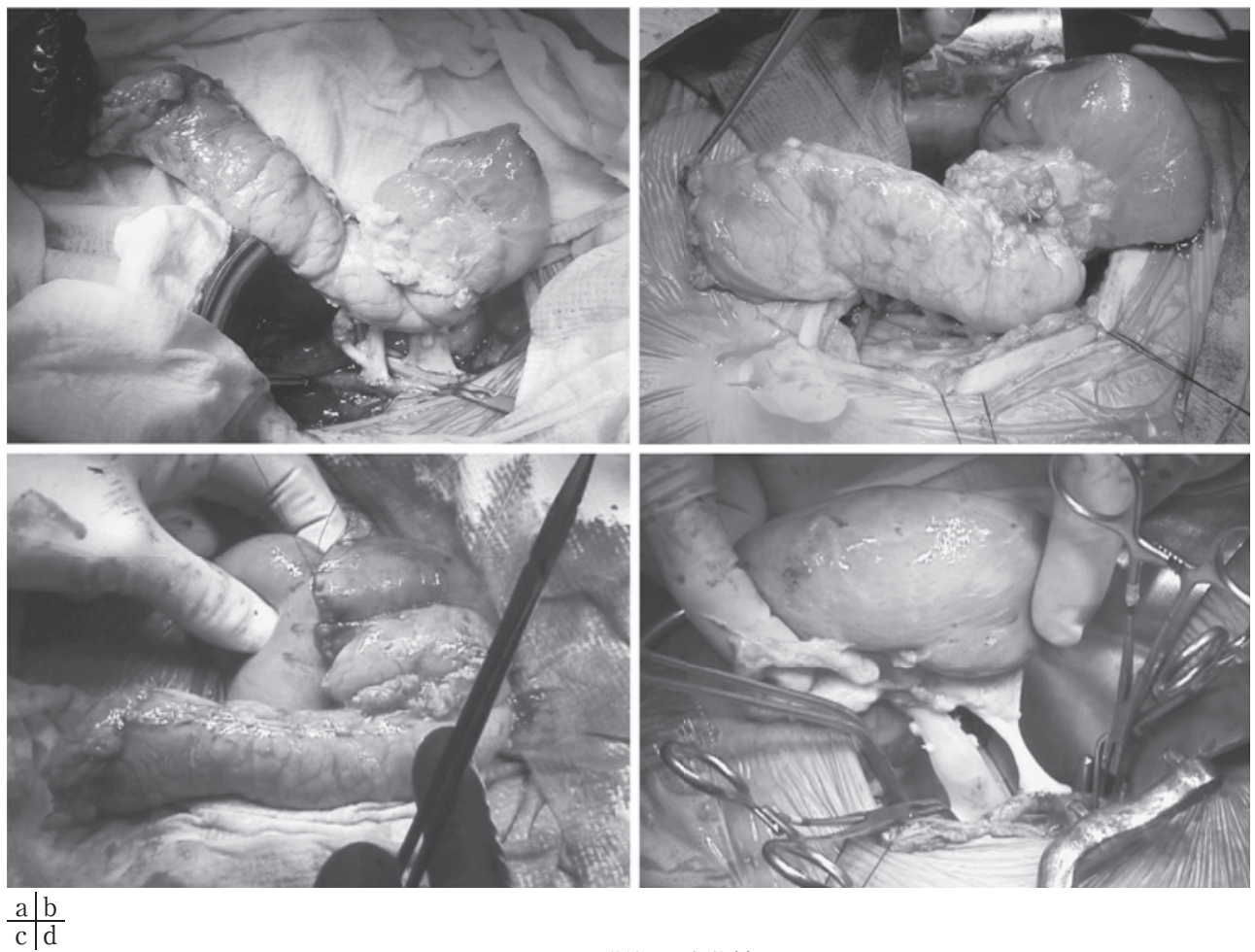

Fig. 5 膵腎同時移植

るか尾側に向けるか，膵液ドレナージの方法を腸 管吻合にするか膀胱吻合にするか，腸管吻合の場 合は Roux-Y 脚かループにするか, 空腸に吻合す るか回腸に吻合するか, 左腸骨窩に移植する場合 はどの組み合わせにするかなどが現在の膵臓移植 の選択肢であろう。かつては脾臓をつけて移植し たり，膵液産生を廃絶するための硬化剂を膵管内 に注入したり，静脈吻合を生理的な上腸間膜静脈 に吻合するなどの方法が行われたこともあった が, 現在は行われていない.

膵腎同時移植の場合，我々は原則として別々の 下腹部斜切開を用いて膵蔵を右腸骨窩の腹腔内 に，腎臓を左腸骨窩の腹腔外に移植して，十二指 腸を尾側に向けることが多い(Fig. 5)。移植膵は, sweating と言われるように, 表面から相当量のリ ンパ液, 膵液を漏出する. 腹腔外に移植すると貯 留霅胞を形成することがあるので腹腔内が好まし いが, その際，滲出液は腹膜，大網などから吸収 される．腹膜癒着や腸管浮腫が懸念されるときは
腹膜外膛を選択している。 また膵グラフト周囲に 感染を起こしたとき移植腎に波及しないように, 腎臓は対側の腹膜外腔に移植する．膵グラフトの 虚血時間をできるだけ短縮するために膵移植を先 行していたが，膵の Bench surgeryを行っている 間に腎移植を別チームで先行することもある.

(1)ファンギゾン $100 \mathrm{mg}$, セファメジン $1 \mathrm{~g}$ を入れ た生食 $500 \mathrm{~m} l$ で膀胱洗浄を行う. 腹部全体を覆 うように消毒, ドレーピングを行う.

(2)膵グラフトは右下腹部の腹腔内に移植する. 腸 骨稜から 2 横指内側で腹直筋外縁におよぶ約 $12 \mathrm{~cm}$ の下腹部斜切開を加え開腹して, Bookwalter 開創器で視野を展開する.

(3)腸骨動静脈の周囲組織を剥離し, 腸骨動脈の硬 化度を調へ，吻合に適した部位をさがす．状況 に応じて腸管吻合, 膀胱吻合のどちらにも対処 できるように，外腸骨動静脈への端側吻合を第 一選択とし，グラフト十二指腸を尾側に向けて いる (Fig. 5a). 
(4)外腸骨静脈に端側で静脈吻合を行うが, 門脈延 長グラフトはできるだけ短く, やや突っ張るぐ らいのほうが血栓を作りにくい. 腸骨静脈に長 めの切込みを入れて 6-0 非吸収糸を用い， 2 点 支持の連続縫合で行う。また，吻合部の口径を 拡げるためにハサミで静脈壁を切り取ることも ある。

(5)動脈吻合は上腸間膜動脈の軸が直線的になるよ うに，静脈吻合より頭側の外腸骨動脈に切り込 みを入れ，6-0 非吸収系を用いて連続端側吻合 を行う。動脈パンチで開けることもある.

(6)血流再開は静脈, 動脈の順に行い, 膵グラフト からの出血を止め脾臓を摘出する (Fig. 5b).

(7)膵液ドレナージ法としては, かつては膀胱吻合 が多用されたが，最近は生理的な腸管吻合を採 用する施設が多い. 多くは空腸を右下に引き出 して，グラフト十二指腸の肛門側端を端側吻合 することが多い(Fig. 5c)，膵蔵はまがたま状に
なり，腸管吻合部が適度に緊張して，腸捻転や イレウスは起こしにくい. 膀胱吻合の場合は, グラフト十二指腸との間に側々吻合を 2 層で行 う.いずれの場合も膵体尾部は上行結腸外側の 腹壁直下に置いて, 術後に超音波検査や生検, 細胞診を行えるようにする，膵液漏があったと きあまり拡がらないように, 小腸は大網で被覆 しておく. 膀胱吻合の場合は, グラフト十二指 腸との間に側々吻合を 2 層で行う。我々は, 原 則として腸管吻合を用いているが, 膵単独移植 の場合, 膵臓を左腸骨窩に植えた場合, 2 度目の 移植の場合は, 膀胱吻合を選択し, 尿中のアミ ラーゼ排出量によって拒絶反応の目安とするよ うにしている。

(8)対側の左腸骨窩の腹膜外腔に腎移植を行う (Fig. 5d)，尿管膀胱吻合は Lich 法で行ってい る.

\title{
Operative techniques for pancreas transplantation in Japan
}

\author{
Atsushi Sugitani*
}

Key words: Pancreas transplantation, Simultaneous pancreas-kidney transplantation, Brain-death donor, Type 1 diabetes mellitus, Chronic kidney disease

Pancreas transplantation and simultaneous pancreas-kidney transplantation(SPK) have been recognized as the best treatment for type 1 diabetic patients. The number of brain-death donors has been increasing in Japan since the revision of the Organ Transplantation Act on July 2010. For the transplant surgeons, appropriate operative techniques for multi-organ procurement from both brain-dead and non-heart-beating donors (from bench surgery including the inspection of the graft and vascular reconstruction) and recipient surgery are necessary in order to achieve successful outcomes.

Procurement of the pancreas from a brain-dead donor is different depending whether removal of the intestine and/or the liver is performed. We usually prioritize the small intestine and first cut the superior mesenteric vessels, proceeding next to the liver to give way to the hepatic artery, the splenic artery and the portal vein. In any case, we use the "Super Rapid Technique" combined with core cooling and surface cooling to reduce excess manipulation and to avoid organ warming during the procurement process. For the recipient operation, we usually position the pancreas graft on the right iliac fossa to anastmose the graft vessels onto the external iliac vessels and to drain pancreatic juice either to the intestine or bladder. In the case of SPK, the kidney graft is usually placed on the opposite side, left iliac fossa extraperitoneally.

Herein, the current standard and most favorable techniques for pancreas transplantation in Japan have been described.

\footnotetext{
* Department of Organ Transplantation and Regenerative Medicine, Fujita Health University (Aichi)
} 